\title{
Can Wetland Vegetation be Used to Describe Anthropogenic Effects and Pollution Patterns? The Case of Dakodwom and Kaase Wetlands in the Kumasi Metropolis, Ghana
}

\author{
Benjamin Betey Campion \\ AG Physiogeographie, Leobnerstr 2. Universität Bremen, 28359 Bremen, Germany \\ Tel: 49-421-2186-3487Ｅ-mail: bbcampion@uni-bremen.de
}

\author{
Simeon Nii Laryea Odametey (Corresponding author) \\ Department of Fisheries and Watershed Management \\ Kwame Nkrumah University of Science and Technology \\ Kumasi, Ghana \\ E-mail: simeonodametey@gmail.com
}

Received: May 17, 2012 Accepted: May 30, 2012 Published: December 31, 2012

doi:10.5296/jee.v3i1.1812ＵRL: http://dx.doi.org/10.5296/jee.v3i1.1812

\begin{abstract}
Wetlands in general are losing their peculiar features, attributes, functions and products although the need to protect them is on the increase globally. Wetlands in Kumasi are not exempted. They are either being converted to other land uses or are directly affected by adjacent land use. Also, the vegetation of the different wetlands in Kumasi varies. This spatial heterogeneity in species of these urban spaces therefore makes management difficult. This research is therefore aimed at using the wetland vegetation to describe anthropogenic effects and pollution patterns in the Kumasi Metropolis, Ghana. Two large riverine wetland areas in Kumasi were selected. All plant species that are within $30 \mathrm{~m}$ from water channel were identified. Heavy metal concentrations and the associated anthropogenic activities in these wetlands were assessed. A total of 48 different plant species were identified in the study areas. Plant species with high importance value index observed at the sites included Ipomoea
\end{abstract}


aquatica, Thalia geniculata, Ipomoea carica, Panicum maximum and Andropogon gayanus. Housing, vegetable farming and car repair shops were the major anthropogenic activities around these wetland areas. Also, all the heavy metals considered in this study were all present in both study sites. The very close similarity in the list of species identified makes it difficult to use vegetation to describe pollution. However, the adjacent anthropogenic activities are the sources of the pollutants and these activities also influence the vegetation.

Keywords: Urbanization, Pollution, Anthropogenic activities, Wetland vegetation, Kumasi 


\section{Introduction}

Africa is endowed with wetlands; accounting for about $10 \%$ of freshwater resources (United Nations Department of Economic and Social Affairs [UN DESA], 2008). This resource is believed to be found virtually in all countries within the continent (UNEP, 2006). According to Koohafkan et al. (1998), the percentage of wetland areas in Africa is approximately 1-16\% of the total area of the continent. It is therefore envisaged that, the potentials of these resources could be harnessed to offer opportunities for improving the livelihood of the local indigents if managed on a sustainable basis (Zedler \& Leach, 1998; Ramsar Convention Secretariat, 2006; Constantini \& Monni, 2008; UN DESA, 2008).

Despite such endowments, Sub-Saharan Africa is considered to be one of the poorest sub-regions in the world (Sahn \& Younger, 2009). One major causal factor is the increase in population growth resulting in a commensurate increase in their dependence on natural resources to meet basic needs. This, unfortunately, has resulted in the encroachment and draining of some wetland ecosystems for other land uses of which urbanization and agriculture are predominant. In Kumasi for instance, most of the riverine systems have only small patches of wetland areas left undisturbed.

Urban wetland vegetation delivers a wide range of ecosystem services relating to climate change mitigation and or adaptation, water catchments, buffer against flooding, purify soil, water and air or act as carbon sinks and contribute to human well-being (Joosten and Clarke, 2002; Berkowitz et al., 2003; Janssen et al., 2005; Nelson et al., 2009). Despite their ecological and socioeconomic importance, urban wetland vegetation has been understudied in the analysis of global environmental change. The focus of urban ecological research has been on contributions of greenhouse gases and the heat island effect to global climate change (Hidalgo et al., 2008; Takebayashi \& Moriyama, 2009). Wetland vegetation is often affected by the hydroperiod or hydrologic changes and availability of nutrients. Also, toxic materials in runoff can interfere with biological processes of wetland plants, resulting in impaired growth, mortality, and changes in plant communities. For example, direct storm sewer inputs, where available, affect plant community structure and vegetation dynamics (Ehrenfeld, 2000). Plants, as individuals or as communities, could therefore be valuable indicators of water regime and other environmental conditions (Haslam, 2003).

Reinelt et al. (1998) in a study on the impacts of urbanization on palustrine wetlands found that, changes in plant community composition may describe impact of pollution. In other studies, it was found that contrary to that of Reinelt et al., vegetation types of different floristic composition or vegetation cover or density are rather predetermined by geomorphology, soil conditions, and water regime (Federal Interagency Committee for Wetlands Delineation, 1989; Barrat-Segretain \& Amoros, 1996; Coroi et al., 2004; Hejcmanovā-Nežerková \& Hejcman, 2006; Sorrell et al., 2007). On a large scale, factors such as soil and climatic conditions may be the determining factors that control the distribution and abundance of vegetation. However, on a small scale, while the soil and climatic conditions may be the same, the vegetation may be very varied. These spatial differences in species distribution may describe specific local differences such as pollution or adjacent 
anthropogenic activities. This research is, therefore, aimed at using the wetland vegetation to describe anthropogenic effects and pollution patterns in the Kumasi Metropolis, Ghana.

\section{Materials and Methods}

Kumasi is a metropolis covering an area of about $254 \mathrm{~km}^{2}$. It is the second largest city in Ghana and the most populous district in the Ashanti region with about 1.2 million inhabitants in 2000. The city is drained by a number of rivers and streams. However, as a result of the effects of the urban sprawl and population growth, the natural environment has been greatly disturbed. In addition to this, the water bodies have been greatly abused from human activities and some of them are near extinction. Most of the remaining patches of greens along most waterways have been cleared for agricultural purposes or are being used as dump sites, car-fitting and -wash sites or carpentry workshops. Some developers have also built along and across watercourses resulting in occasional flooding. Dakodwom and Kaase wetlands have relatively large stretches of wetland vegetation. These two wetland areas are drained by different streams and have different anthropogenic pressures that make each of them unique and suitable for this comparative study.

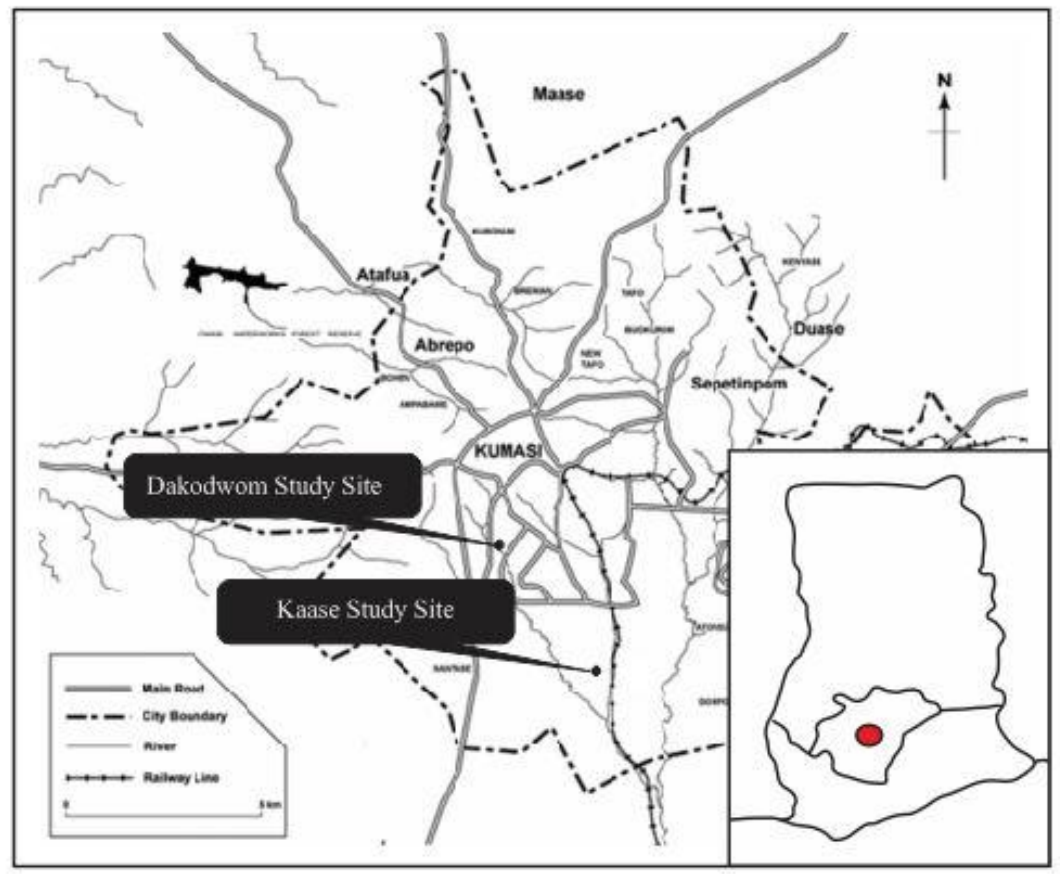

Figure 1. Location of the study sites Dakodwom and Kaase in Kumasi

Soil samples were collected using a stainless steel trier sampler at Dakodwom and Kaase following standard procedures described by the U.S. EPA (Municipal Environmental Research Laboratory, 1980) in the dry season (January) and rainy season (June) of 2011. Soils from each site were oven dried for 48 hours to obtain a fairly constant oven dry weight. The dried samples were crumbled mechanically and passed through a sieve with $2 \mathrm{~mm}$ mesh and stored in plastic bottles until chemical analysis were carried out. Precautions were observed to ensure there were no sources of contamination. Trace metals concentrations were 
determined after acid extraction using an atomic absorption spectrometer (Varian SpectrAA-200FS). All the reagents and chemicals employed were of analytical grade.

From the metal concentrations measured, the enrichment factor (EF), geo-accumulation index $\left(\mathrm{I}_{\text {geo }}\right)$ and pollution load index (PLI) were used to assess the heavy metal pollution in both sites. Iron $(\mathrm{Fe})$ was chosen as the element for normalisation of the enrichment because natural sources vastly dominate its input in the environment (Schiff \& Weisberg, 1999; Ghrefat \& Yusuf, 2006; Sekabira et al., 2010). To obtain the Fe concentration in the wetland sediments of Kumasi, three sediment samples were taken from different locations in the KNUST Botanical Gardens and pooled. This site was chosen because of its remoteness from known or suspected anthropogenic metal sources. World geochemical background values in average shale as reported by Turekian \& Wedepohl (1961) were used for all the metals. The EF for each metal was computed as the relative abundance of species in the sediment to that found in the Earth's crust (Simex \& Helz, 1981) with the formula:

$$
\mathrm{EF}=\frac{R}{F_{\theta}}(\text { sediment }) / \frac{R}{F_{\theta}}(\text { Earth's crust })
$$

Where $\mathrm{X}$ is concentration of the metal

studied.

Six categories of enrichment were recognised: <1 background concentration, 1-2 depletion to minimal enrichment, 2-5 moderate enrichment, 5-20 significant enrichment, 20-40 very high enrichment and >40 extremely high enrichment (Duzgoren-Aydin et al., 2006; Harikumar et al., 2010).

The $I_{\text {geo }}$ values were calculated for the different metals using the formula of Müller (1969) expressed as: $I_{\text {geo }}=\log _{2}\left(C_{n} / 1.5^{*} B_{n}\right)$. Where $C_{n}$ is the measured concentration of element $n$ in the sediment sample and $B_{n}$ is the geochemical background for the element $n$. The factor 1.5 is introduced to include possible variation of the background values that are due to lithogenic variations. Müller (1969) proposed seven sediment quality classes associated with the geoaccumulation index as given in Table 1 .

Table 1. Classes of the geoaccumulation index used to define sediment quality

\begin{tabular}{|l|l|l|}
\hline$I_{\text {geo }}$ value & $I_{\text {geo }}$ Class & Quality of sediment \\
\hline$\leq 0$ & 0 & Unpolluted \\
\hline $0-1$ & 1 & From unpolluted to moderately polluted \\
\hline $1-2$ & 2 & Moderately polluted \\
\hline $2-3$ & 3 & From moderately to strongly polluted \\
\hline $3-4$ & 4 & Strongly polluted \\
\hline $4-5$ & 5 & From strongly to extremely polluted \\
\hline$\geq 6$ & 6 & Extremely polluted \\
\hline
\end{tabular}

The PLI is an indicator of site quality. For each metal, the contamination factor (CF) was first determined using the formula, $\mathrm{CF}=$ metal concentration in sediments/background values of 


\section{Macrothink}

the metal. The extent of pollution by trace metals was assessed using the PLI formula developed by Tomlinson et al. (1980): PLI $=\left(\mathrm{CF}_{1} * \mathrm{CF}_{2} * \ldots . . * \mathrm{CF}_{\mathrm{n}}\right)^{1 / \mathrm{n}}$

Where $\mathrm{CF}=$ contamination factor and $\mathrm{n}=$ number of metals. PLI value $>1$ is polluted whereas PLI value $<1$ indicates no pollution.

For vegetation sampling, the systematic sampling approach described by Orloci (1978) was adopted. In each wetland (for example Wetland A as shown in figure 2), three sampling sites were demarcated at about $50 \mathrm{~m}$ apart. A line transect was laid perpendicularly across the river. Along the line transects on each side of the river, the quadrat was positioned at about $10 \mathrm{~m}$ intervals starting from the periphery of the river channel. In each quadrat, all species were identified and their cover and abundance recorded according to the Braun - Blanket scale as shown in Table 2 (Coroi et al. 2004). Species which could not be identified on the field were photographed, described and recorded in the field notebook for later identification. This was done in the rainy and dry seasons. The associated anthropogenic activities on either side and within $100 \mathrm{~m}$ from the water channel were recorded.

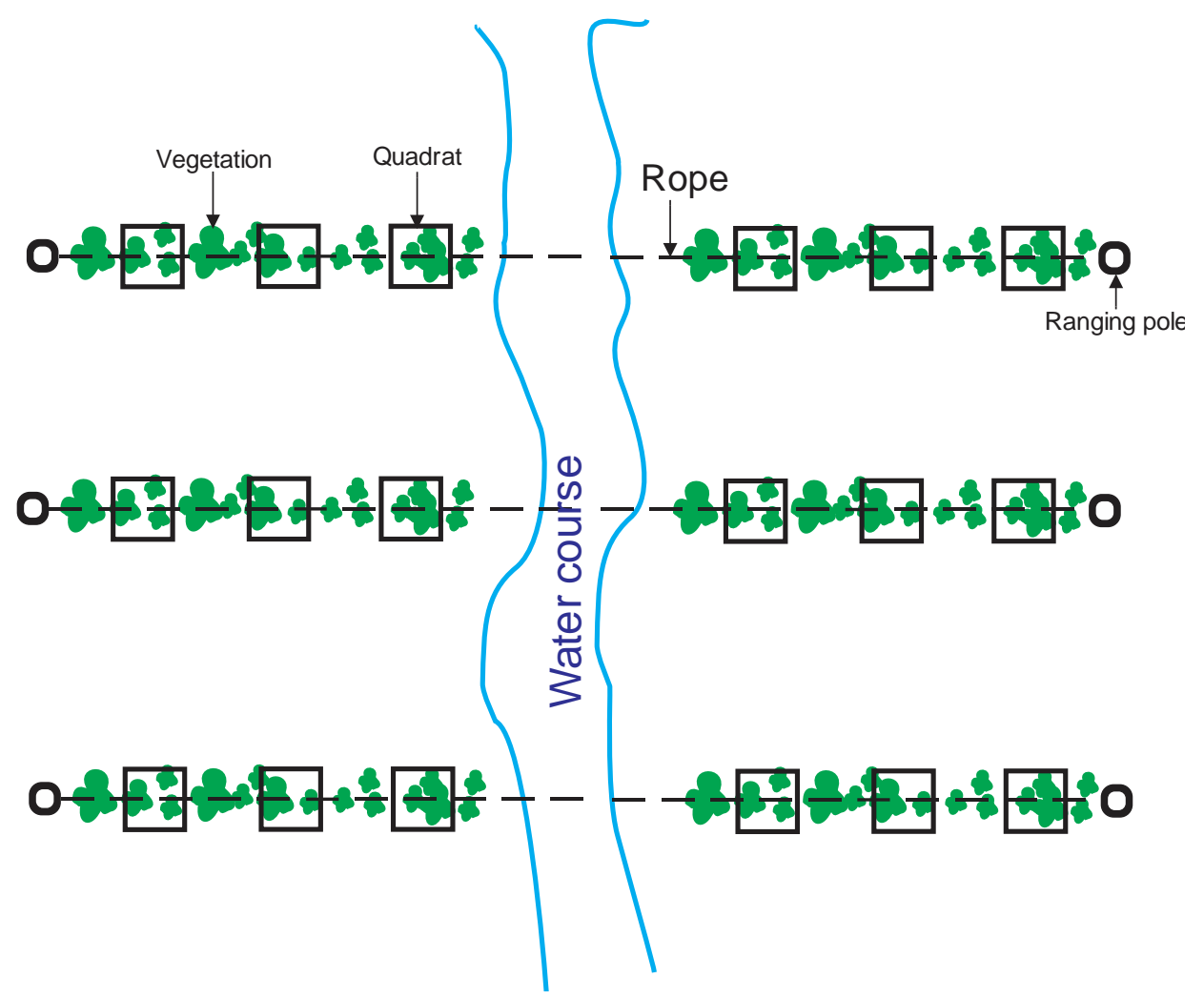

Figure 2. Schematic drawing of the line transect method in a sample wetland A. 
Table 2. The Braun - Blanquet Scale used for the study of wetland vegetation in Kumasi

\begin{tabular}{|c|c|c|c|}
\hline $\begin{array}{l}\text { Braun-Blanquet } \\
\text { scale }\end{array}$ & $\begin{array}{l}\text { Range of } \\
\text { cover }(\%)\end{array}$ & Relative abundance & $\begin{array}{l}\text { Midpoint } \\
\text { of over } \\
\text { range }(\%)\end{array}$ \\
\hline 5 & $75-100$ & \multirow{2}{*}{ very common, usually single spp. Dominant } & 87.5 \\
\hline 4 & $50-75$ & & 62.5 \\
\hline 3 & $25-50$ & $\begin{array}{l}\text { common, dominance is shared by } 2 \text { to } 3 \text { other } \\
\text { spp }\end{array}$ & 37.5 \\
\hline 2 & $5-25$ & $\begin{array}{l}\text { frequent, a spp not sharing dominance but } \\
\text { remains significant to the composition of the site }\end{array}$ & 15.0 \\
\hline 1 & $\begin{array}{l}<5 ; \\
\text { numerous } \\
\text { individuals }\end{array}$ & occasional occurrence & 2.5 \\
\hline+ & $\begin{array}{l}<5 ; \text { few } \\
\text { Individuals }\end{array}$ & $\begin{array}{l}\text { rare, individuals infrequently seen, low count } \\
\text { and crown cover }\end{array}$ & 0.1 \\
\hline
\end{tabular}

The Shannon diversity, Margalef richness, Pielou evenness and the importance value indices were used to characterize the vegetation distribution. Graphs of Shannon, Margalef and Pielou indices were plotted against distance away from the water channel (at about $10 \mathrm{~m}$ intervals) to find out if there were any spatial patterns.

Statistical tests were employed to find out if there were any differences in the index values (Shannon diversity, Pielou's evenness and Margalef's richness) calculated at the various points where samples were taken. The Kruskal-Wallis test was employed to detect within site differences and the Mann Whitney test was used for between site differences.

\section{Results}

The human population in these suburbs has been growing steadily. The population trajectory from 1970 revealed a polynomial growth in Kaase whereas Dakodwom had a linear growth (Figure 3). The increasing population of these suburbs means an associated increase in anthropogenic activities and environmental effects over the years. Several anthropogenic activities were identified on and adjacent to these wetlands (Figure 4). For both areas natural vegetation is the greatest land cover. Kaase had more houses and farming activities within the $100 \mathrm{~m}$ zone of the wetland area as compared to Dakodwom (Figure 4). Although waste is disposed of at several places in the wetland, its cover is relatively small. 


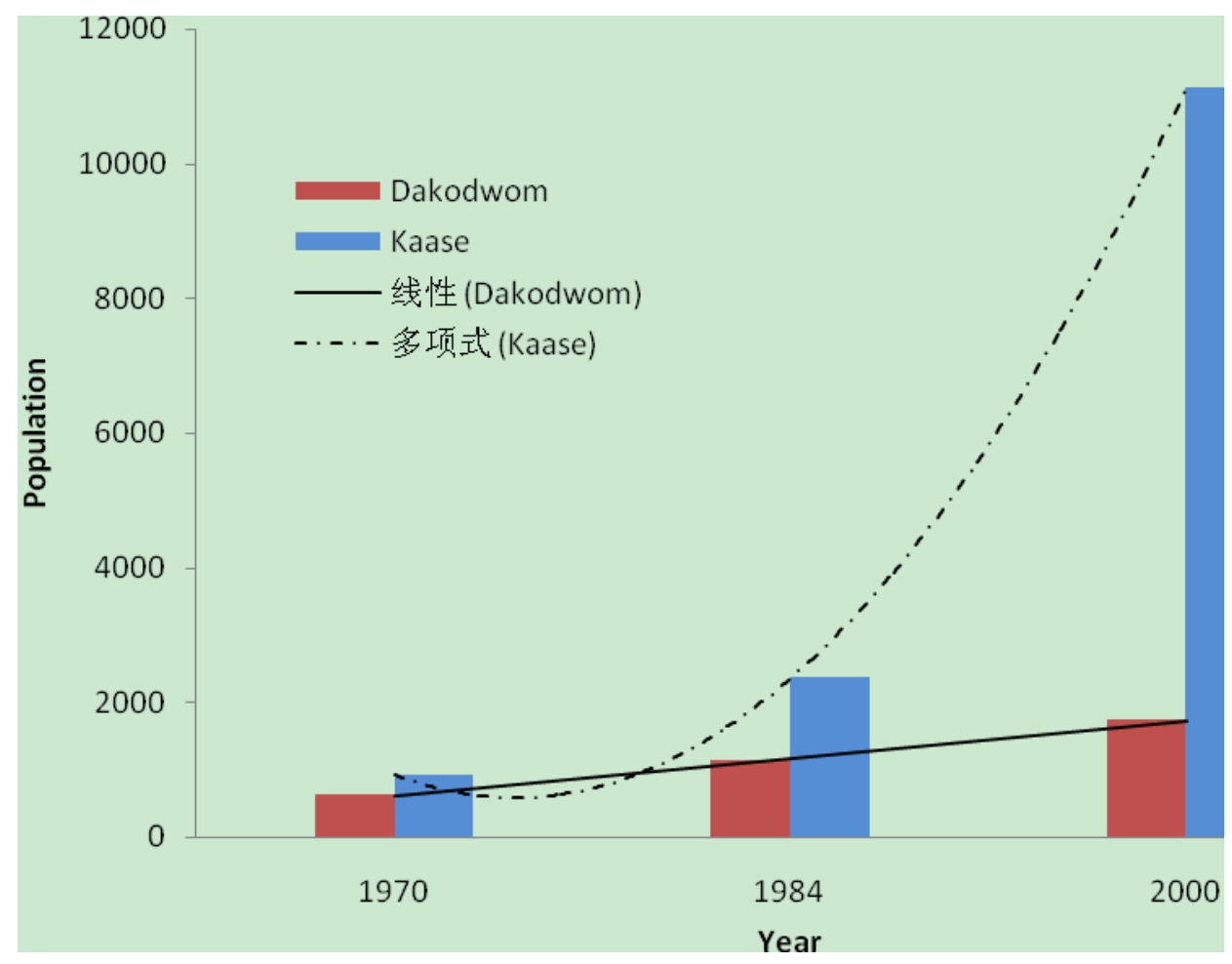

Figure 3. Population trends for suburbs of Dakodwom and Kaase in Kumasi

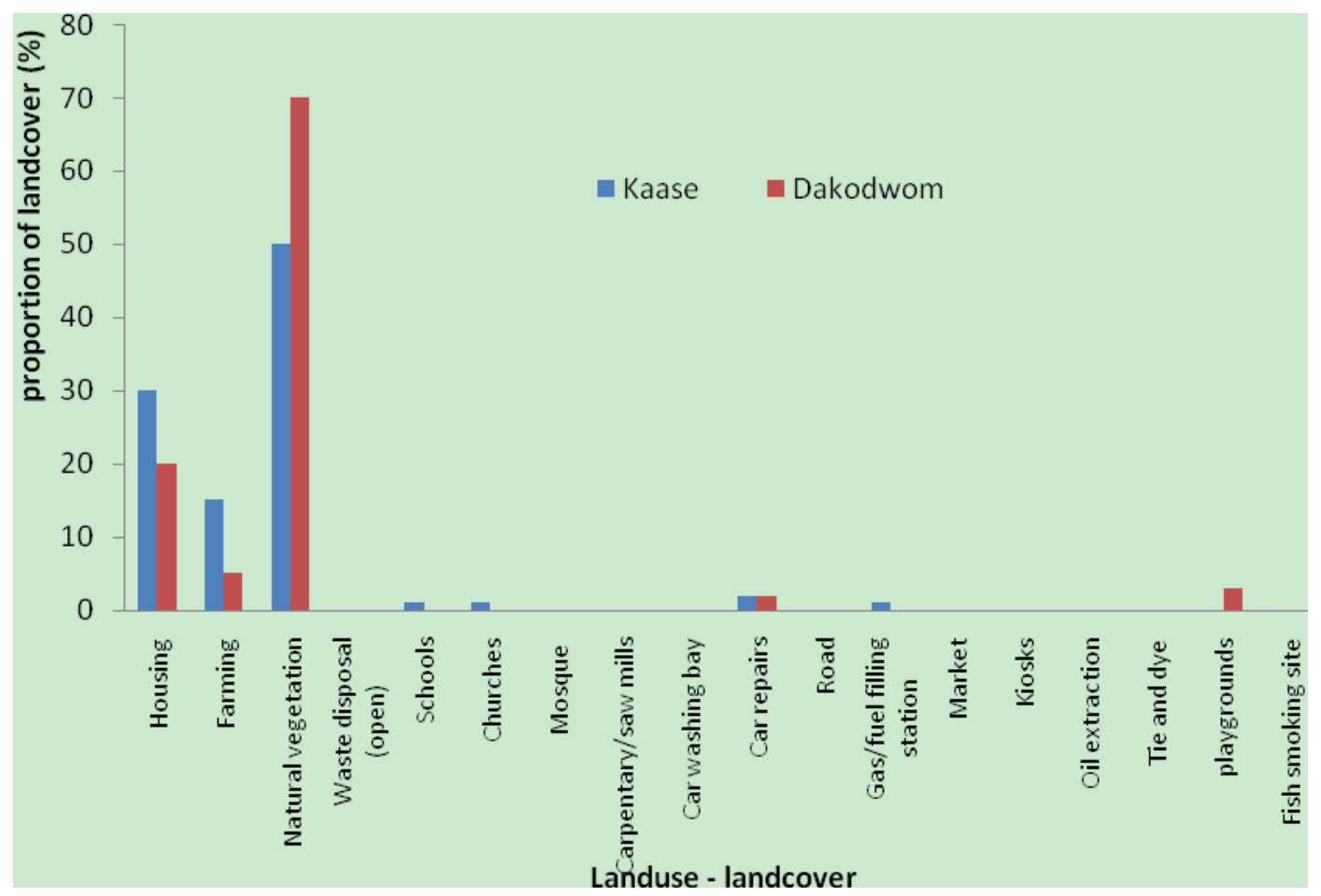

Figure 4. Landcover and landuse activities identified at Kaase and Dakodwom 


\section{Macrothink}

Generally, the $\mathrm{I}_{\text {geo }}$ for the various heavy metals were considerably lower in magnitude in the rainy seasons as compared to those in the dry seasons (Figure 5a). Whereas $I_{\text {geo }}$ for arsenic, copper, lead and phosphorus describe a condition of "moderately to strongly polluted" in Kaase during the dry season, only lead and phosphorus were considered to be "moderately to strongly polluted" in Dakodwom. Heavy metal enrichments in the sediments were also generally lower in the rainy season than the dry the season (see Figure 5b). In Kaase for instance, significant enrichment occurred for arsenic, copper, lead, zinc, chromium and phosphorus in the dry season whiles only copper, zinc, lead and phosphorus were significantly enriched in Dakodwom. The PLI results suggested that both sites were polluted (see figure 6). The results, however, show there was more deterioration in environmental quality in the dry season for Kaase and Dakodwom than the rainy season.

a)

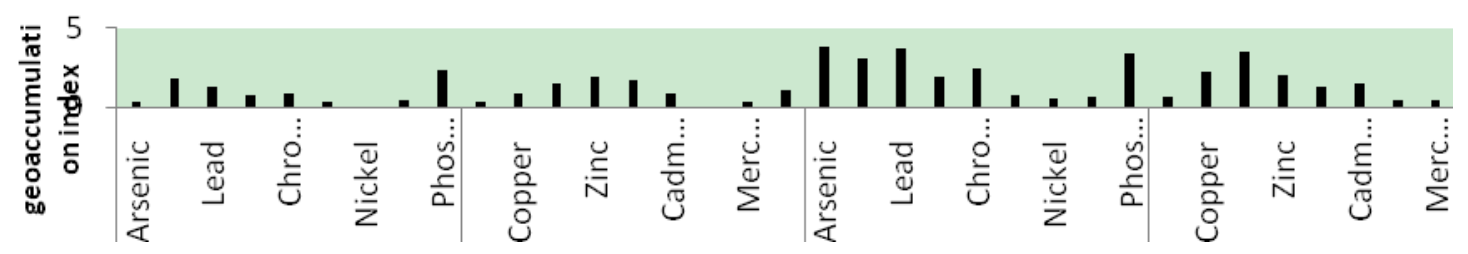

b)

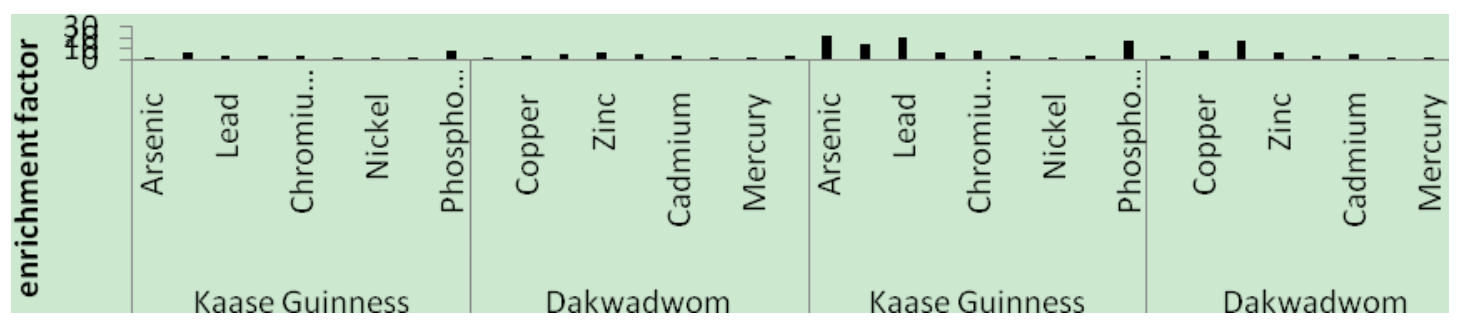

Figure 5. Geoaccumulation index (a) and Enrichment factor (b) values for Dakodwom and Kaase in both rainy and dry seasons

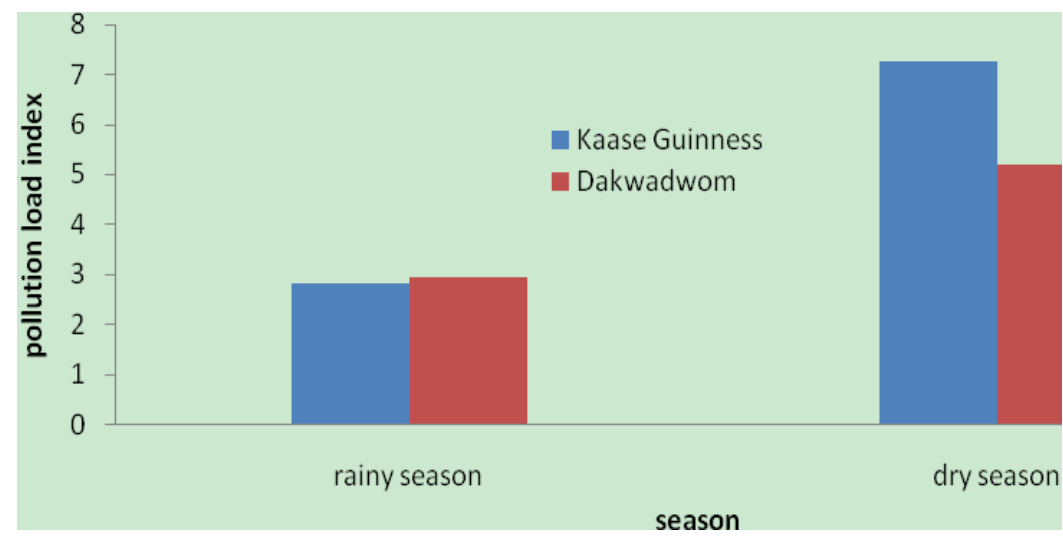

Figure 6. Pollution Load for Kaase and Dakodwom in both rainy and dry season. 


\section{Ml Macrothink}

Journal of Environment and Ecology

ISSN 2157-6092

2012, Vol. 3, No. 1

A total of 48 plant species were identified from the two wetland areas. There were no seasonal differences in species in both wetlands so the results were pooled (Table 3). The importance value index was used to describe the vegetation distribution. Kaase had more species with relatively higher importance values. Thalia geniculata and Ipomoea aquatica were the two most important plant species observed on the Dakodwom wetland with importance indices of 64.1 and 17.2 respectively. Species like Cyperus haspan, Colocasia esculenta, Euphobia hirta, Luffa cylindrical and Syndrella nodiflora had relatively smaller importance indices. Another important observation was the pullulation of Colocasia esculenta on the dump sites. However, this species never occurred in other transects where there were no refuse dumps on the site. At Dakodwom, Andropogon gayanus and Panicum maximum were also the most important species observed with importance indices of 47.9 and 35.1 respectively. Plant species common to both sites included Cyperus haspan, Ipomea aquatica, Thalia geniculata, Ipomoea carica, Panicum maximum, and Andropogon gayanus. Statistical tests results for "within and between site differences" indicated a no significant difference in both cases.

Table 3. List of species identified in the different wetlands of Kumasi

\begin{tabular}{|l|l|l|l|l|l|}
\hline & Kaase & $\begin{array}{l}\text { Importance } \\
\text { value }\end{array}$ & & Dakodwom & $\begin{array}{l}\text { Importance } \\
\text { value }\end{array}$ \\
\hline 1 & Achyranthes aspera & 8.55 & 1 & Aeschynomene crassicalulis & 8.68 \\
\hline 2 & Agerantum conyzoides & 5.01 & 2 & Amaranthus spinosus & 2.75 \\
\hline 3 & Alchornea cordifolia & 6.10 & 3 & Andropogon gayanus & 47.95 \\
\hline 4 & Amaranthus spinosus & 28.23 & 4 & Aspila Africana & 2.76 \\
\hline 5 & Andropogon gayanus & 8.46 & 5 & Bidens pilosa & 10.24 \\
\hline 6 & Boerhavia diffusa & 6.10 & 6 & Centrocema pubecens & 5.52 \\
\hline 7 & Cassia acidentalis & 6.29 & 7 & Chromolaena odorata & 17.11 \\
\hline 8 & Chromolaena odorata & 12.59 & 8 & Commelina benghalensis & 14.23 \\
\hline 9 & Coix lacryma - jobi & 6.79 & 9 & Commelina erecta & 3.36 \\
\hline 10 & Colocasia esculenta & 2.45 & 10 & Crotalara spectabilis & 5.78 \\
\hline 11 & Commelina benghalensis & 7.21 & 11 & Cyperus alternifolius & 11.35 \\
\hline 12 & Cyperus alternifolius & 2.32 & 12 & Cyperus haspan & 3.64 \\
\hline 13 & Cyperus haspan & 2.84 & 13 & Cyperus longibracteatus & 13.12 \\
\hline 14 & Cyperus longibracteatus & 9.96 & 14 & Cyperus rotundus & 19.23 \\
\hline 15 & Cyperus rotundus & 8.22 & 15 & Elusine indica & 4.33 \\
\hline 16 & Euphobia hirta & 2.35 & 16 & Euphorbia hetrophila & 19.25 \\
\hline 17 & Euphorbia hetrophila & 3.23 & 17 & Imperata cylindrica & 4.21 \\
\hline 18 & Imperata cylindrica & 10.44 & 18 & Ipomoea aquatica & 15.43 \\
\hline 19 & Ipomoea aquatica & 17.22 & 19 & Ipomoea asarifolia & 11.23 \\
\hline 20 & Ipomoea asarifolia & 2.45 & 20 & Ipomoea carica & 9.31 \\
\hline 21 & Ipomoea carica & 12.20 & 21 & Ipomoea involucrata & 13.25 \\
\hline 22 & Ipomoea involucrata & 41.73 & 22 & Justica flava & 2.76 \\
\hline 23 & Limnocharis flava & 3.20 & 23 & Ludwigia abysinica & 11.23 \\
\hline & & & & \\
\hline
\end{tabular}




\begin{tabular}{|l|l|l|l|l|l|}
\hline 24 & Ludwigia abyssinica & 8.04 & 24 & Ludwigia deccurens & 5.69 \\
\hline 25 & Luffa cylindrica & 2.94 & 25 & Luffa cylindrica & 9.87 \\
\hline 26 & Mimosa pigra & 4.62 & 26 & Momordica charantia & 12.21 \\
\hline 27 & Nicotiana tabacum & 5.60 & 27 & Oldenlandia corymbosa & 2.76 \\
\hline 28 & Panicum maximum & 13.96 & 28 & Panicum maximum & 35.06 \\
\hline 29 & Pennisetum polystachion & 3.14 & 29 & Phyllanthus amarus & 19.21 \\
\hline 30 & Phyllanthus amarus & 10.21 & 30 & Sorghum arundinaceum & 17.32 \\
\hline 31 & Setaria barbata & 3.43 & 31 & Thalia geniculata & 2.57 \\
\hline 32 & Sida garckeana & 7.27 & 32 & Typha australis & 18.23 \\
\hline 33 & Sorghum arundinaceum & 13.21 & & & \\
\hline 34 & Syndrella nodiflora & 2.74 & & & \\
\hline 35 & Thalia geniculata & 64.17 & & & \\
\hline 36 & Thelypteris palustris & 5.50 & & & \\
\hline 37 & Typha australis & 16.98 & & & \\
\hline
\end{tabular}

The results for the Shannon, Margalef's richness and Pielou's evenness indices did not follow any specific pattern of distribution. As such, the data was modelled using non-parametric regression to simplify the distribution. Generally, the modelled curves for the indices at Dakodwom show a gradual rise in the curves for Shannon and species richness indices through to the $30 \mathrm{~m}$ mark (Figures 7 and 9 respectively). Species evenness on the other hand decreased gradually to the $30 \mathrm{~m}$ mark (see Figure 8 ).

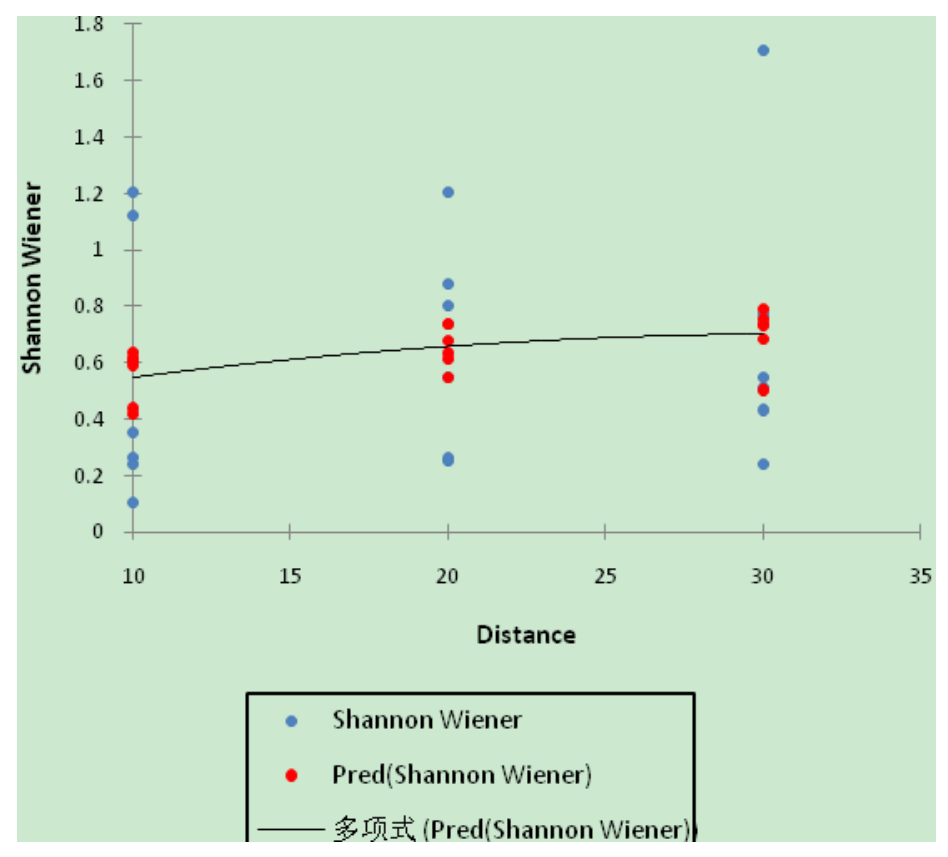

Figure 7. Pattern of Shannon index with respect to distance from the water channel at Dakodwom 


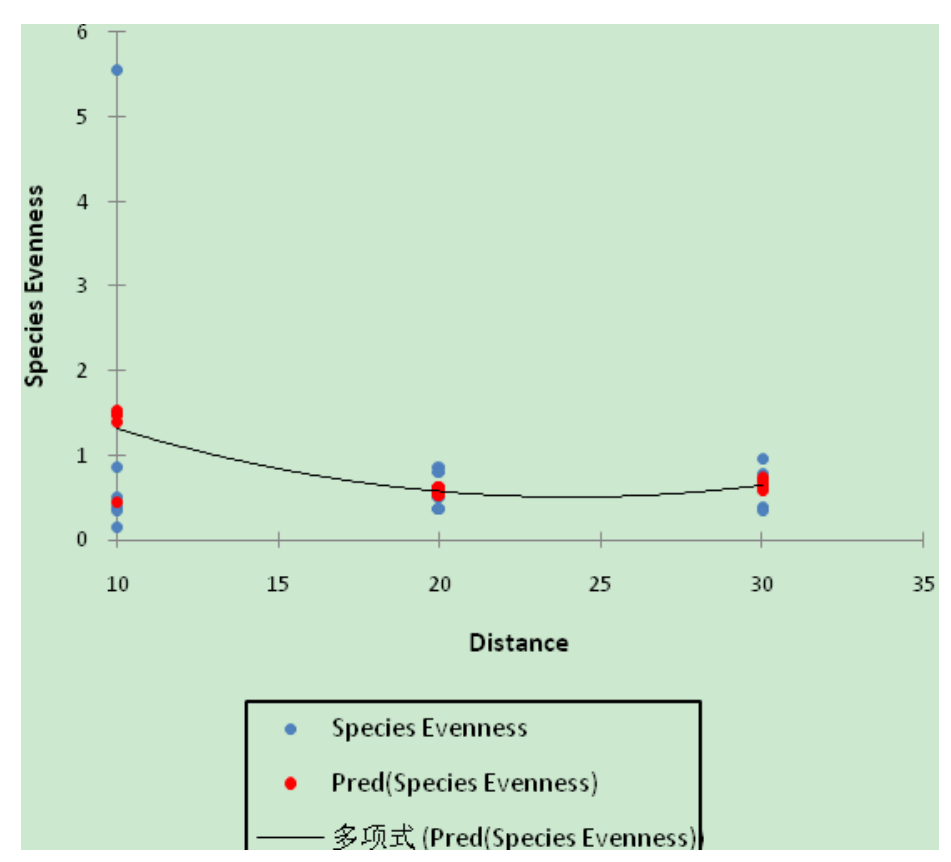

Figure 8. Pattern of Pielou's species evenness with respect to distance from the water channel at Dakodwom

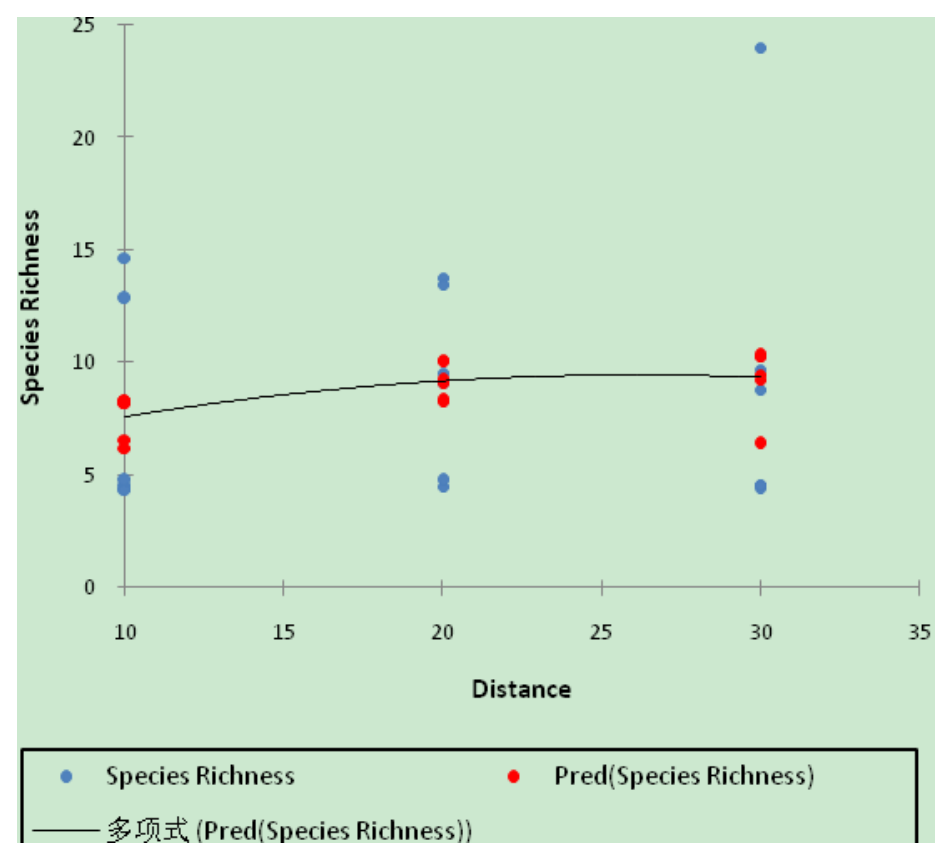

Figure 9. Pattern of Margalef's species richness with respect to distance from the water channel at Dakodwom

In the case of Kaase, the modelled data displayed a gradual increase of the Shannon and species evenness indices from the $10 \mathrm{~m}$ mark to the $20 \mathrm{~m}$ mark and a fall in the $30 \mathrm{~m}$ mark 


\section{Macrothink}

Journal of Environment and Ecology

ISSN 2157-6092 2012, Vol. 3, No. 1

(Figures 10 and 11 respectively). Species richness, on the other hand, was observed to decrease gradually to the $30 \mathrm{~m}$ mark (Figure 12).

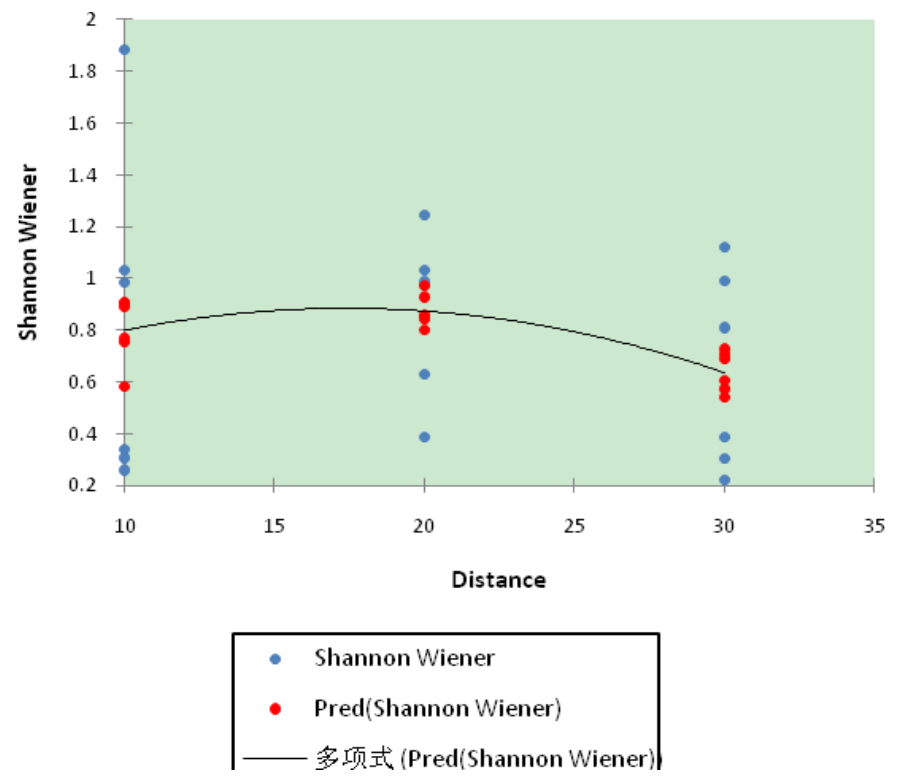

Figure 10. Pattern of Shannon diversity index with respect to distance from the water channel at Kaase

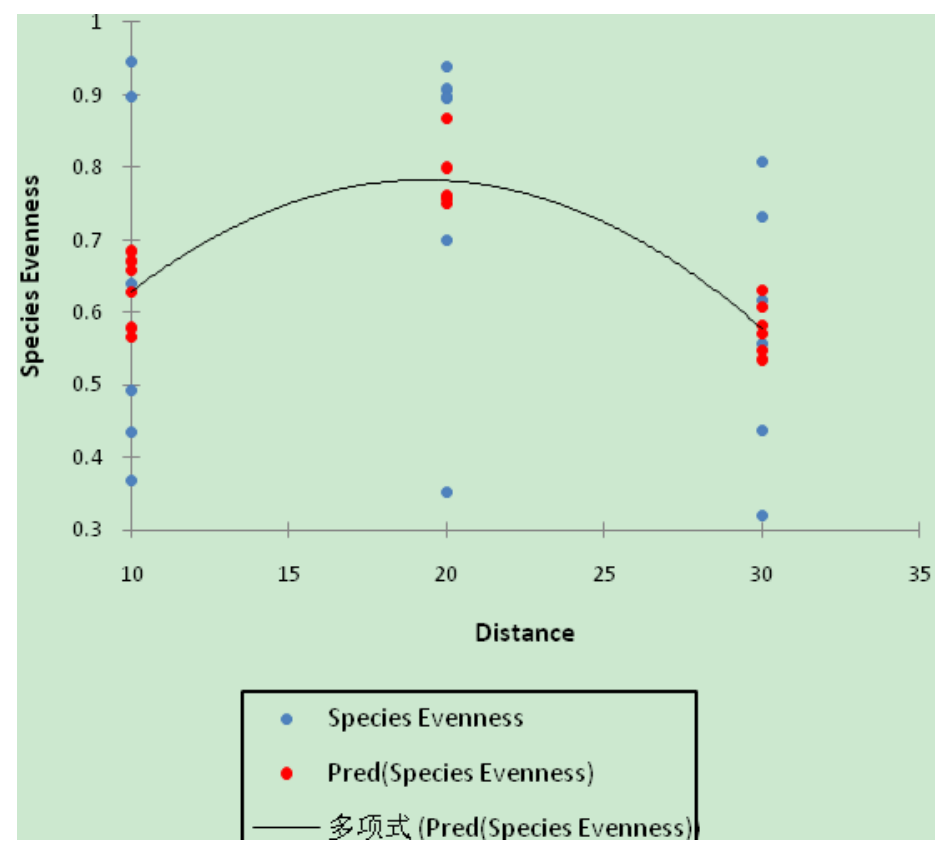

Figure 11. Pattern of Pielou's species evenness with respect to distance from the water channel at Kaase 


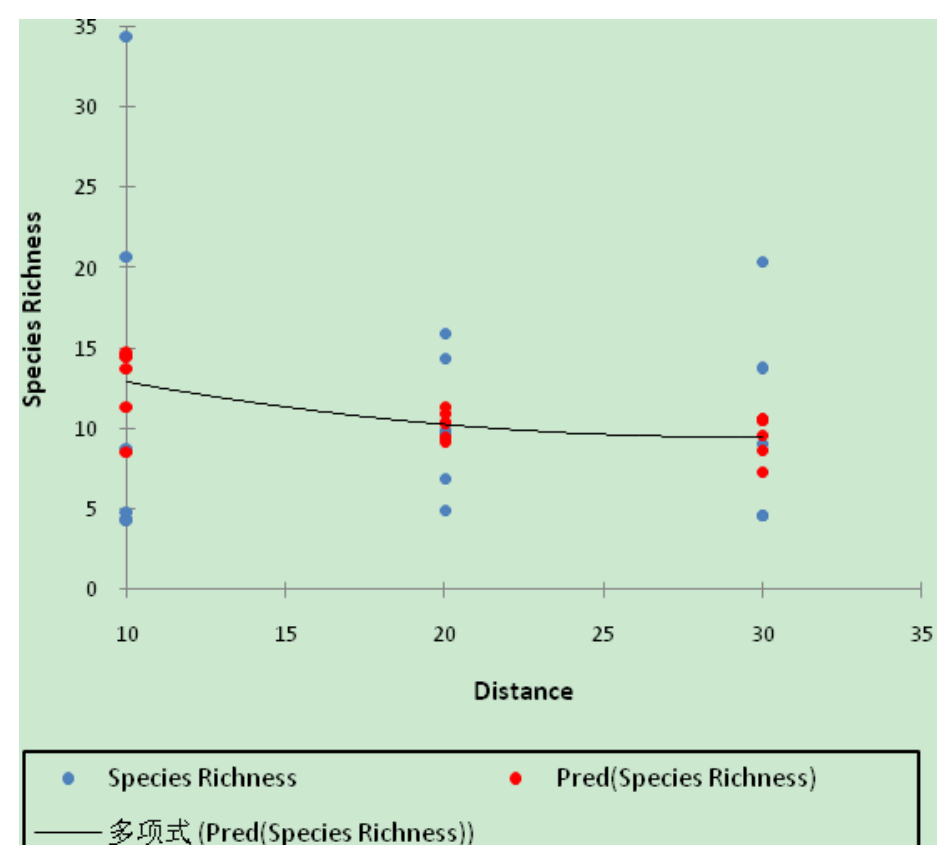

Figure 12. Pattern of Margalef's species richness with respect to distance from the water channel at Kaase

\section{Discussion}

According to the population census data and pollution indices employed in this study, both wetlands could be described as polluted. The seasonal variation in degree of heavy metal contamination may be related to the variations in physicochemical conditions especially $\mathrm{pH}$ and dissolved oxygen. Heavy metal concentrations in sediments depend not only on their input sources but also upon the ability of the sediment to retain the metals (Chakravarty \& Patgiri, 2009). Variations in physicochemical conditions could therefore affect the metal retention in the sediments. According to Schropp \& Windom (1998), when dissolved metals from natural or anthropogenic sources come in contact with saline water, they quickly adsorb to particulate matter and are removed from the water column to bottom sediments. The seasonality recorded here could also be due to relatively higher levels of erosion in the rainy season which washes away precipitated and adsorbed metals than the dry season. Even though trace amounts from terrigenous sources are indispensable, the relatively high levels of metal contamination in both sites could be attributed to inputs from adjacent anthropogenic activities.

Attempts to clearly relate the influence of heavy metal concentration to vegetation distribution patterns have been very difficult. Several reasons could be given to account for this enigma. It was not possible to isolate specific metal-vegetation relationships or effects from the data collected. Therefore, the variations in the vegetation distribution patterns could have emanated from other environmental factors and anthropogenic disturbances (specific to the different sites) other than the heavy metals. If all these factors could be held constant with the exception of a specific heavy metal, it would have been expected that different plant 
species would have different responses to the metal uptake and tolerance, consequently affecting plant growth and distribution. The presence or absence of a particular species and its growth habit and characteristics could then be used to characterise a particular heavy metal. However, the effect of heavy metals in the current results cannot be entirely ruled out.

Other explicitly plausible factors could be anthropogenic activities such as agricultural practices and use of wetlands as dump sites. These activities may influence the line of succession which in turn could alter the richness, evenness and the abundance of plant species on the sites. The prevalence of some species at some sites might be due to some human induced initial conditions that favoured the growth and development of these species. This could be a plausible explanation to the dominance of Colocasia esculenta in quadrats that are in or close to dump sites in the various wetlands in Kumasi. The land use changes due to agriculture and conversion to dump sites could result in alterations in the hydrology, input of autochthonous and allochthonous material as well as changes in the water chemistry of the wetland leading to changes in the local plant community (Owen, 1999). In a similar study in Kumasi, Campion and Venzke (2011) found that the hydrology was the major determinant of wetland vegetation distribution. It was found that, the presence or absence of water on the surface of the land in the form of pools may also introduce within wetland differences in species composition and distribution. Wetland species will have different levels of tolerance to different physicochemical properties of the pools and therefore varying spatial distribution from the water channel.

Typical of tropical environments, the study sites had very diverse vegetation as expressed by the indices (Burslem et al., 2005). However, it is difficult to use these levels of diversity as a standard for describing wetlands in Kumasi because of the varying levels of anthropogenic activities in urban wetlands. The intermediate disturbance hypothesis may hold true for these study sites and, thus, explain the observed changes in species distribution from the water channel (Dial \& Roughgarden 1998). It is also worthy to state that, even though no two quadrat plots can be exactly the same, the edaphic differences may not be sharp between the quadrat plots to produce distinct differences in species along the distances that were considered for this study. Even though this study did not investigate obligate and facultative wetland species, the association of species with high importance values to flooded sites very much defines the very unique niches that characterize such species in the environment. As such, the sites of obligate high importance value species could be delineated to define the wetland microcosms.

The various indices of pollution showed that Kaase is more polluted. Also, all the heavy metals considered in this study were all identified in both study sites. These pollutants affect the physicochemical conditions of the respective wetlands and, therefore, affect these wetland plants. The question then arises as to whether the wetland vegetation in the study sites can be used to describe the pollution patterns and anthropogenic activities. The very close similarity in the list species identified makes this difficult. The important species of Kaase e.g. Thalia geniculata and Ipomea aquatica are obligate wetland species whilst those at Dakodwom e.g. Andropogon gayanus and Panicum maximum are facultative. In contrast to Campion and Venzke (2011), hydrology may therefore not be the only controlling factor for plant 
distribution in these two sites. The adjacent anthropogenic activities are the sources of the pollutants and also influence the vegetation.

\section{References}

Barrat-Segretain, M. H., \& Amoros, C. (1996). Recovery of riverine vegetation after experimental disturbance: a field test of the patch dynamics concept. Hydrobiologia, 321, 53-68. http://dx.doi.org/10.1007/BF00018677

Berkowitz, A. R., Nilon, C. H., \& Hollweg, K. S. (Eds), (2003). Understanding Urban Ecosystems: A New Frontier for Science and Education. Sringer-Verlang New York, Inc.

Burslem D. F. R. P., Pinard, M. A., \& Hartley, S. E. (Eds) (2005). Biotic Interactions in the Tropics: Their Role in the Maintenance of Species Diversity. Cambridge University Press, $580 \mathrm{pp}$

Campion, B. B., \& Venzke, J. F. (2011). Spatial patterns and determinants of wetland vegetation distribution in the Kumasi Metropolis, Ghana. Wetlands Ecology and Management, 19, 423-431. http://dx.doi.org/10.1007/s11273-011-9226-2

Chakravarty, M., \& Patgiri, A. D. (2009). Metal Pollution Assessment in Sediments of the Dikrong River, N.E. India. Journal of Human Ecology, 27(1), 63-67.

Coroi, M., Skeffington, M. S., Giller, P., Smitha, C., Gormally M., \& O’Donovand, G. (2004). Vegetation diversity and stand structure in streamside forests in the south of Ireland. Forest Ecology and Management, 202, 39-57. http://dx.doi.org/10.1016/j.foreco.2004.06.034

Dial R., \& Roughgarden, J. (1988). Theory of marine communities: the intermediate $\begin{array}{llll}\text { disturbance } \quad \text { hypothesis. } & \text { Ecology, } & 79, & 1412-1424 .\end{array}$ http://dx.doi.org/10.1890/0012-9658(1998)079[1412:TOMCTI]2.0.CO;2

Duzgoren-Aydin, N. S., Wong, C. S. C., Aydin, A., Song, Z., You, M., \& Li, X. D. (2006). Heavy metal contamination and distribution in the urban environment of Guangzhou, SE China. Environmental Geochemistry and Health, 28, 375-391. http://dx.doi.org/10.1007/s10653-005-9036-7

Ehrenfeld G. J. (2000). Evaluating wetands within an urban context. Urban Ecosystems, 4, 69-85. http://dx.doi.org/10.1023/A:1009543920370

Federal Interagency Committee for Wetlands Delineation. (1989). Federal Manual for identifying and delineating jurisdictional wetlands. US Government Printing Office, Washington, DC, 76pp.

Ghrefat, H., \& Yusuf, N. (2006). Assessing Mn, Fe, Cu, Zn, and Cd pollution in bottom sediments of Wadi Al-Arab Dam, Jordan. Chemosphere, 65, 2114-2121. http://dx.doi.org/10.1016/j.chemosphere.2006.06.043

Harikumar, P. S., Prajitha, K., \& Silpa, S. (2010). Assessment of heavy metal contamination in the sediments of a river draining into a Ramsar site in the Indian sub-continent. Journal of Advanced Laboratory Research in Biology, 1(2), 157-169 
Haslam, S. M. (2003). Understanding Wetlands: fen, bog and marsh. London, Taylor and Francis Group. http://dx.doi.org/10.1201/9780203634189

Hejcmanovā-Nežerková, P., \& Hejcman, M. (2006). A canonical correspondence analysis (CCA) of the vegetation-environment relationships in Sudanese savannah, Senegal. South African Journal of Botany, 72, 256 - 262. http://dx.doi.org/10.1016/j.sajb.2005.09.002

Hidalgo, J., Masson, V., Baklanov, A., Pigeon, G., \& Gimeno, L. (2008). Advances in urban climate modelling. Annals of the New York Academy of Sciences, 1146, 354-74. http://dx.doi.org/10.1196/annals.1446.015

Janssen, R., Goosena, H., Verhoevenb, M. L., Verhoevenb, J. T. A., Omtzigta, A. Q. A., \& Maltby, E. (2005). Decision support for integrated wetland management. Environmental Modelling and Software, 30, 215-229. http://dx.doi.org/10.1016/j.envsoft.2003.12.020

Joosten, H., \& Clarke, D. (2002). Wise Use of Mires and Peatlands- Background and Principles Including a Framework for Decision-making. International Mire Conservation group and International Peat Society. Pp.304

Koohafkan, P., Nachtergaele F., \& Antoine, J. (1998). Use of agro-ecological zones and resource management domains for sustainable management of African wetlands. Wetland Characterization and Classification for Sustainable Agricultural Development. FAO/SAFR, Rome.

Müller, G. (1969). Index of geoaccumulation in the sediments of the Rhine River. Geojournal, $2,108-118$

Municipal Environmental Research Laboratory. (1980). Samplers and Sampling Procedures for Hazardous Waste Streams. Environmental protection technology series. EPA - 600/2 - 80 $-018$.

Nelson, K. C., Palmer, M. A., Pizzuto, J. E., Moglen, G. E., Angermeier, P. L., Hilderbrand, R. H., Dettinger, M., \& Hayhoe, K. (2009). Forecasting the combined effects of urbanization and climate change on stream ecosystems: from impacts to management options. Journal of Applied Ecology, 46(1), 154-163. http://dx.doi.org/10.1111/j.1365-2664.2008.01599.x

Owen, C. R. (1999). Hydrology and history: land use changes and ecological responses in an urban wetland. Wetlands Ecology and Management, 6, 209-219. http://dx.doi.org/10.1023/A:1008488022466

Reinelt, L., Horner, R., \& Azous, A. (1998). Impacts of urbanization on palustrine (depressional freshwater) wetlands - research and management in the Puget Sound region. Urban Ecosystems, 2, 219-236. http://dx.doi.org/10.1023/A:1009532605918

Sahn, D. E., \& Younger, S. D. (2007). Living standards in Africa. Cornell Food and Nutrition Policy Program Working Paper No. 225. http://dx.doi.org/10.2139/ssrn.1008061 


\section{Macrothink}

Journal of Environment and Ecology

ISSN 2157-6092

2012, Vol. 3, No. 1

Schiff, K. C., \& Weisberg, S. B. (1999). Iron as a reference element for determining trace metal enrichment in Southern California coast shelf sediments. Marine Environmental Research, 48, 161-176. http://dx.doi.org/10.1016/S0141-1136(99)00033-1

Schropp, S. J., \& Windom, H. L. (Eds) (1988). A guide to the interpretation of metal concentrations in estuarine sediments. Office of Water Policy, Florida Department of Environmental Protection, Tallahassee

Sekabira, K., Oryem Origa, H., Basamba, T. A., Mutumba, G., \& Kakudidi, E. (2010). Assessment of heavy metal pollution in the urban stream sediments and its tributaries. International Journal of Environmental Science and Technology, 7(3), 435-446

Simex, S. A., \& Helz, G. R. (1981). Regional geochemistry of trace elements in Checapeake Bay. Environmental Geology, 3, 315-323. http://dx.doi.org/10.1007/BF02473521

Sorrell, B. K., Partridge, T. R., Clarkson, B. R., Jackson, R. J., Chague'-Goff, C., Ekanayake, J., Payne, J., Gerbeaux, P., \& Grainger, N. P. J. (2007). Soil and vegetation responses to hydrological manipulation in a partially drained polje fen in New Zealand. Wetlands Ecology and Management, 15, 361-383. http://dx.doi.org/10.1007/s11273-007-9035-9

Sutherland R. A., Tolosa C. A., Tack F. M. G., \& Verloo M. G. (2000). Characterization of selected element concentration and enrichment ratios in background and anthropogenically impacted roadside areas. Archives of Environmental Contamination and Toxicology, 38, 328 - 438. http://dx.doi.org/10.1007/s002449910057

Takebayashi, H., \& Moriyama, M. (2009). Study on the urban heat island mitigation effect achieved by converting to grass-covered parking. Solar Energy, 83(8), 1211-1223 http://dx.doi.org/10.1016/j.solener.2009.01.019

Turekian, K. K., \& Wedepohl, K. H. (1961). Distribution of the elements in some major units of the earth's crust. Geological Society of America Bulletin, 72, 175-192 http://dx.doi.org/10.1130/0016-7606(1961)72[175:DOTEIS]2.0.CO;2

UN DESA. (2008). Trends in Sustainable Development: Africa Report, 2008/2009. United Nations publication. ISBN 978-92-1-104576-5

UNEP. (2006). Africa Environment Outlook 2: Our Environment, Our Wealth. United Nations Environment Programme, Nairobi. ISBN: 92-807-2691-9. UNEP Job No. DEW/0801/NA 